\title{
RESEARCH
}

Open Access

\section{Blockchain government - a next form of infrastructure for the twenty-first century}

MyungSan Juni

\author{
Correspondence: ulcaman@gmail. \\ com \\ BlockchainOS Inc., Seoul, Republic \\ of Korea
}

\begin{abstract}
Today, more than 100 blockchain projects created to transform government systems are being conducted in more than 30 countries. What leads countries rapidly initiate blockchain projects? I argue that it is because blockchain is a technology directly related to social organization; Unlike other technologies, a consensus mechanism form the core of blockchain. Traditionally, consensus is not the domain of machines but rather humankind. However, blockchain operates through a consensus algorithm with human intervention; once that consensus is made, it cannot be modified or forged. Through utilization of Lawrence Lessig's proposition that "Code is law," I suggest that blockchain creates "absolute law" that cannot be violated. This characteristic of blockchain makes it possible to implement social technology that can replace existing social apparatuses including bureaucracy. In addition, there are three close similarities between blockchain and bureaucracy. First, both of them are defined by the rules and execute predetermined rules. Second, both of them work as information processing machines for society. Third, both of them work as trust machines for society. Therefore, I posit that it is possible and moreover unavoidable to replace bureaucracy with blockchain systems. In conclusion, I suggest five principles that should be adhered to when we replace bureaucracy with the blockchain system: 1) introducing Blockchain Statute law; 2) transparent disclosure of data and source code; 3) implementing autonomous executing administration; 4) building a governance system based on direct democracy and 5) making Distributed Autonomous Government(DAG).
\end{abstract}

At the time I initially planned to investigate the subject of blockchain technology and government, I could not imagine that so many blockchain projects were underway in so many countries. Moreover, the speed of expansion of government-led blockchain projects worldwide is astonishing. For example, Estonia has used blockchain technology to issue e-ID for identity verification for their citizens. Additionally, electronic voting systems based on blockchain are being built in many countries including Ukraine, Estonia, and Australia. Honduras and Georgia attempted to introduce blockchain technology to manage their land registers. The United States is working to incorporate blockchain technology to record and share medical information, and the UK is pursuing research and development to apply blockchain technology to public services. ${ }^{1}$ China has announced plan to build a "Blockchain city," based on blockchain technology. In addition, more than 100 blockchain projects are being conducted in more than 40 countries around the world. IBM reported that nine in 10 governments will invest in Blockchain projects by $2018 .^{3}$

(c) The Author(s). 2018 Open Access This article is distributed under the terms of the Creative Commons Attribution 4.0 International License (http://creativecommons.org/licenses/by/4.0/), which permits unrestricted use, distribution, and reproduction in any medium, provided you give appropriate credit to the original author(s) and the source, provide a link to the Creative Commons license, and indicate if changes were made. 


\section{Various blockchain projects led by governments}

Actually, there are so many projects that are conducted by governments. One can see the projects driven by governments around the world in the tables below. ${ }^{4}$ Table 1 contains various projects conducted by governments except voting system and digital currency projects. Table 2 contains the electronic voting system projects based on blockchain, and Table 3 contains the digital currency projects based on blockchain around the world. (Please note that not all projects are listed. There are much more projects than listed in tables below.)

What leads countries to rapidly initiate blockchain projects? In this article, I will argue that it is due to blockchain technology being directly related to social organization. Unlike other technologies, a consensus mechanism forms the core of blockchain. Traditionally, consensus is not the domain of machines but rather humankind. However blockchain operates through a consensus algorithm with human intervention. Consensus algorithms work every moment when the blockchain decides what data should be regarded as genuine and therefore stored in the blockchain. Blockchain has a structure in which all the participants validate the data and all the participants store the original version of the verified data.

Therefore, once the data is confirmed, which is synonymous with consensus being made and data stored in blockchain, it cannot be modified or forged. ${ }^{5}$ Blockchain is a cutting-edge social and physical technology that simultaneously makes possible an immutable and tamper-proof system. Thus, blockchain is an optimal technology for dealing with public data that should not be forged. However, the blockchain is not simply a data storage technique. With the smart contracts feature that comes with blockchain technology, it goes much further that it has the potential to replace existing social organizations.

\section{Social technology}

I think it would be helpful to adopt the concept of 'social technology' to understand the features of blockchain technology. To understand the concept of social technology, we first must distinguish between two kinds of technologies; "physical technology" and "social technology". In addition to physical technology, which involves the transformation and modification of things with engineering and scientific knowledge, there is another kind of technology that we can call "social technology." The concept of social technology comes from the analysis of Richard Nelson and Katherine Nelson ${ }^{6}$ who distinguished physical technology from social technology. In short, Social technology is defined as ways to communicate, cooperate, compromise, and make consensus with other people. Social technology contains the division of labor, social institutions, and decision making process in communities. Social technology refers to the technology that directly affects the structure of society, systems, social relations, and individual interactions. Social technology is a concept that allows us to identify and analyze these features of technology.

However, physical technology and social technology are also interwoven. Physical technology influences social technology and enables the construction of new social technology. ${ }^{7}$ For example, Internet technology allows people to communicate together immediately, regardless of their physical locations. Therefore, some smart people have endeavored to develop unpreceded physical technology to improve existing social technologies or to make a new social technology. (I think the effort of Satoshi Nakamoto who invented the blockchain technology ${ }^{8}$ is an exact case of these kinds of efforts.) 
Table 1 Examples of government-led blockchain projects

\begin{tabular}{|c|c|c|}
\hline Nation & Project & Status \\
\hline \multirow[t]{2}{*}{ Australia } & $\begin{array}{l}\text { Australian senators launch parliamentary } \\
\text { friends of blockchain group. }\end{array}$ & Announced in August 9, 2017 \\
\hline & $\begin{array}{l}\text { The Australian Securities Exchange (ASX) } \\
\text { announced that they will use blockchain } \\
\text { technology to clear and settle trades by } \\
\text { replacing the outdated Clearing House } \\
\text { Electronic Subregister System, also known } \\
\text { as CHESS. }\end{array}$ & $\begin{array}{l}\text { Announced in December, } 2017 . \\
\text { The proposed transition is } \\
\text { expected to take place in March } \\
2018 .\end{array}$ \\
\hline \multirow[t]{4}{*}{ China } & Social security funds management system & Announced in 2016 \\
\hline & Mortgage valuations on blockchain & Announced in 2016 \\
\hline & $\begin{array}{l}\text { Blockchain-based asset custody system } \\
\text { (PSBC) }\end{array}$ & $\begin{array}{l}\text { Successfully executed more than } 100 \\
\text { real business transactions on the } \\
\text { blockchain since the system went live } \\
\text { in October } 2016\end{array}$ \\
\hline & Blockchain city project (By Wanxiang Group) & $\begin{array}{l}\text { The project was announced by Wanxiang } \\
\text { Group in } 2016 \text { and backed by Chinese } \\
\text { government }\end{array}$ \\
\hline \multirow[t]{4}{*}{ Dubai } & $\begin{array}{l}\text { Government documents management } \\
\text { system to be enacted by } 2020\end{array}$ & Ongoing \\
\hline & $\begin{array}{l}\text { Global blockchain council (GBC) was } \\
\text { established in } 2016 \text { with } 32 \text { members, } \\
\text { including government entities, } \\
\text { international companies, leading UAE } \\
\text { banks, free zones, and international } \\
\text { blockchain technology firms }\end{array}$ & Ongoing \\
\hline & Digital passport based on blockchain & Announced in June 2017 \\
\hline & $\begin{array}{l}\text { Real-time information system about } \\
\text { shipments to Dubai }\end{array}$ & Announced in 2017 \\
\hline \multirow[t]{3}{*}{ Estonia } & elD (electronic ID management system) & $\begin{array}{l}\text { The government is currently upgrading } \\
\text { the existing system with blockchain } \\
\text { technology. }\end{array}$ \\
\hline & $\begin{array}{l}\text { E-health (medical information management } \\
\text { system) }\end{array}$ & $\begin{array}{l}\text { The government is currently upgrading } \\
\text { the existing system with blockchain } \\
\text { technology. }\end{array}$ \\
\hline & $\begin{array}{l}\text { e-Residency (a first-of-a-kind a transnational } \\
\text { digital identity) }\end{array}$ & $\begin{array}{l}\text { Since 2015, more than 27,000 people from } \\
143 \text { countries have applied and } 4272 \\
\text { companies have been established as of } \\
\text { December } 2017\end{array}$ \\
\hline France & $\begin{array}{l}\text { French government has adopted new rules } \\
\text { that will enable banks and fintech firms to } \\
\text { establish blockchain platforms for unlisted } \\
\text { securities trading. }\end{array}$ & Announced in December, 2017 \\
\hline Ghana & Land title registry project by NGO "Bitland" & Ongoing \\
\hline Georgia & Land title registry project & Ongoing \\
\hline Honduras & Land title registry project & $\begin{array}{l}\text { Announced in } 2015 \text { and known as failure } \\
\text { now }\end{array}$ \\
\hline Kazakhstan & $\begin{array}{l}\text { Announced that they will make the most } \\
\text { favorable business climate for cryptocurrency } \\
\text { and Financial technology(Fintech) }\end{array}$ & Announced in July 17, 2017 \\
\hline \multirow[t]{2}{*}{ Russia } & $\begin{array}{l}\text { Blockchain based documents management } \\
\text { system announced by Moscow government }\end{array}$ & Announced in 2016 \\
\hline & $\begin{array}{l}\text { Russia's ministry of health is launching a } \\
\text { blockchain pilot }\end{array}$ & Announced in Aug 10, 2017 \\
\hline Singapore & Cross-border interbank payments & $\begin{array}{l}\text { A proof-of-concept project has been } \\
\text { initiated in } 2016 \text {. }\end{array}$ \\
\hline Sweden & $\begin{array}{l}\text { Trials of a blockchain smart contracts } \\
\text { technology for land registry }\end{array}$ & Tested in early 2017 \\
\hline
\end{tabular}


Table 1 Examples of government-led blockchain projects (Continued)

\begin{tabular}{|c|c|c|}
\hline Nation & Project & Status \\
\hline \multirow[t]{2}{*}{ Switzerland } & $\begin{array}{l}\text { The city of Zug (the capital of the canton of } \\
\text { Zug) started accepting bitcoin as payment for } \\
\text { city fees. The large number of companies } \\
\text { engaged in cryptocurrency are located in } \\
\text { Crypto Valley in Zug }\end{array}$ & $\begin{array}{l}\text { Since July } 2016 \text { (Crypto Valley was } \\
\text { named by Ethereum co-founder Mihai } \\
\text { Alisie) }\end{array}$ \\
\hline & $\begin{array}{l}\text { Zug offers blockchain-based digital identity } \\
\text { to their residents }\end{array}$ & Announced in 2017 \\
\hline $\begin{array}{l}\text { The United Arab } \\
\text { Emirates and } \\
\text { Saudi Arabia }\end{array}$ & $\begin{array}{l}\text { The central banks of the United Arab Emirates } \\
\text { and Saudi Arabia announced that they would } \\
\text { launch a pilot initiative that two institutions } \\
\text { test a new cryptocurrency for cross-border } \\
\text { payments. }\end{array}$ & Announced in December, 2017 \\
\hline \multirow[t]{2}{*}{ Ukraine } & $\begin{array}{l}\text { E-vox (Ethereum blockchain-based election } \\
\text { platform) }\end{array}$ & Announced in 2016 \\
\hline & Blockchain-based auction system & Announced in 2016 \\
\hline \multirow[t]{4}{*}{$\begin{array}{l}\text { United } \\
\text { Kingdom (UK) }\end{array}$} & $\begin{array}{l}\text { The UK government's Department of Work } \\
\text { and Pensions tested an experiment in which a } \\
\text { blockchain system is used to distribute welfare } \\
\text { payments. }\end{array}$ & $\begin{array}{l}\text { Announced in July } 2016 \text { and successfully } \\
\text { finished trail system }\end{array}$ \\
\hline & $\begin{array}{l}\text { Blockchain as a service for each government } \\
\text { department }\end{array}$ & Available since August 2016 \\
\hline & Blockchain-based digital currency & $\begin{array}{l}\text { UK's Financial Conduct Authority (FCA) } \\
\text { permitted blockchain startup, Tramonex, } \\
\text { to issue digital money }\end{array}$ \\
\hline & $\begin{array}{l}\text { Blockchain-based payment system between } \\
\text { banks }\end{array}$ & Announced in 2017 \\
\hline \multirow[t]{5}{*}{$\begin{array}{l}\text { United States } \\
\text { (US) }\end{array}$} & $\begin{array}{l}\text { Pilot project for secure exchange of personal } \\
\text { health data online }\end{array}$ & $\begin{array}{l}\text { A two-year agreement for the tests was } \\
\text { announced in } 2016\end{array}$ \\
\hline & $\begin{array}{l}\text { Approving plan to issue stock via Bitcoin's } \\
\text { blockchain (Securities and Exchange } \\
\text { Commission) }\end{array}$ & Announced in 2015 \\
\hline & $\begin{array}{l}\text { Arizona bill to make blockchain smart } \\
\text { contracts "legal" }\end{array}$ & $\begin{array}{l}\text { Officially became state law in March 29, } \\
2017\end{array}$ \\
\hline & $\begin{array}{l}\text { Governor of Delaware has officially signed a } \\
\text { bill making it explicitly legal for those entities } \\
\text { to use blockchain for stock trading and } \\
\text { record-keeping. }\end{array}$ & Announced in July 2017 \\
\hline & $\begin{array}{l}\text { Illinois launches blockchain pilot to digitize } \\
\text { birth certificates }\end{array}$ & Announced in Aug 31, 2017 \\
\hline
\end{tabular}

Indeed, the history of humankind has been interwoven with the development of technology. In twenty-first century society, individuals do not interact directly through the face-to-face communication. It is now common that technology mediates the interactions of individuals. We now use technologies everyday such as email, BBS, mobile messages, messengers, SNS etc. In this sense, the nature and characteristics of technology that weaves between individuals and individuals, individuals and groups, or groups and groups become an important subject. We are now facing Blockchain technology.

The reason why blockchain is expected to change social organization is because it can replace the role played by existing social technologies including the bureaucracy, the most elaborate and dominant organization form in modern society. 
Table 2 Electronic voting systems based on blockchain around the world

\begin{tabular}{|c|c|c|c|}
\hline Nation or Organization & System Name & Base Technology & Application \\
\hline $\begin{array}{l}\text { Abu Dhabi Securities } \\
\text { Exchange (Stock Exchange) }\end{array}$ & - & - & $\begin{array}{l}\text { Shareholder voting } \\
\text { system }\end{array}$ \\
\hline Australia Postal Service & - & $\begin{array}{l}\text { Digital Assets } \\
\text { Holdings }\end{array}$ & $\begin{array}{l}\text { Digital voting of } \\
\text { Victoria government }\end{array}$ \\
\hline Denmark Liberal Alliance & Follow My Vote & $\begin{array}{l}\text { Graphene Blockchain } \\
\text { Framework }\end{array}$ & $\begin{array}{l}\text { Ballot system for } \\
\text { political party }\end{array}$ \\
\hline Estonia & i-Voting & KSI & National voting system \\
\hline $\begin{array}{l}\text { London Stock } \\
\text { Exchange(LSE) }\end{array}$ & - & Hyperledger & $\begin{array}{l}\text { Shareholder voting } \\
\text { system }\end{array}$ \\
\hline Moscow government & - & Ethereum & $\begin{array}{l}\text { Digital voting of } \\
\text { Moscow government }\end{array}$ \\
\hline Nasdaq & - & - & $\begin{array}{l}\text { Shareholder voting } \\
\text { system }\end{array}$ \\
\hline Podemos (Spain) & Agora-Voting & Bitcoin & $\begin{array}{l}\text { Ballot system for political } \\
\text { party }\end{array}$ \\
\hline Texas Libertarian Party & $\begin{array}{l}\text { VoteWatcher (by Blockchain } \\
\text { Technologies Corp) }\end{array}$ & Florincoin Blockchain & $\begin{array}{l}\text { Ballot system for political } \\
\text { party }\end{array}$ \\
\hline Ukraine & E-vox & Ethereum & $\begin{array}{l}\text { Voting system for various } \\
\text { voting }\end{array}$ \\
\hline Utah Republican party & Blockchain Apparatus & $\begin{array}{l}\text { Smartmatic (private } \\
\text { blockchain) }\end{array}$ & $\begin{array}{l}\text { Ballot system for political } \\
\text { party }\end{array}$ \\
\hline
\end{tabular}

\section{Weak coercion, strong coercion, and absolute coercion}

Here, however, a new problem arises. Because of the ways in which technology mediates individuals, individuals interact with each other in ways defined by technology. That is, new technology allows individuals to interact in an unprecedented manner, while also restricting them to interact within the limits of "the specific way that the technology allows." This implies that technology can be considered a coercive force that restricts individuals' activities.

Particularly in our era, the coercive force of technology should not be treated trivially. We are moving to an automated algorithm society ${ }^{9}$ based on artificial intelligence coupled with big data already. Algorithms are composed of logic and control. An algorithm society is a society wherein the coercive force of algorithms is generalized in society as a whole. The software that implements the algorithm is not merely a collection of strings written in a software language, but an enforcing constraint that specifically limits how individuals behave and how they interact within these technologies. Therefore, Professor Lawrence Lessig formulated the proposition "Code is Law" or "Code as Law" to capture this idea. ${ }^{10}$

Blockchain is also an algorithm implemented by software. In particular, the Smart Contracts $^{11}$ feature, which is regarded as the greatest potential of the blockchain, makes it possible to set rules that define conditions for executing pre-defined contracts automatically. ${ }^{12}$ In other words, because of the nature of the blockchain that prevents it from being hacked or faked, the code of Smart Contracts in blockchain has a coercive force. Blockchain makes it possible to build an "absolute law" that cannot be forged or violated.

Therefore, I distinguished three types of coercion: weak coercion, strong coercion, and absolute coercion. The coercion in the laws of the real world is a "weak coercion." It is a type of coercion that can be violated if you choose to violate it, such as ignoring the red light when crossing the road. The enforcement that is implemented in the 
Table 3 Digital currency projects based on blockchain

\begin{tabular}{|c|c|c|}
\hline Status & Nation & Status \\
\hline \multirow[t]{3}{*}{ In use } & Barbados & Launched a blockchain-based version of the Barbadian dollar in 2016. \\
\hline & Tunisia & Upgraded the e-dinar with blockchain based technology in 2016. \\
\hline & Senegal & $\begin{array}{l}\text { Launched a blockchain-based version of the eCFA(digital currency) in } 2016 . \\
\text { This currency will be used as the official currency of The Western African } \\
\text { Economic and Monetary Union. }\end{array}$ \\
\hline \multirow[t]{15}{*}{$\begin{array}{l}\text { Pilot testing or } \\
\text { considering }\end{array}$} & Canada & $\begin{array}{l}\text { 'Project Jasper' phase II was started at December } 2016 \text { and announces phase } \\
3 \text { of 'Project Jasper' DLT Trial in October, } 2017 .\end{array}$ \\
\hline & China & Completed a trial run of digital currency in January 2017. \\
\hline & Denmark & Planning to Introduce E-Krone based on blockchain in February 2017. \\
\hline & England & Approved the digital currency issued by fintech company in 2016. \\
\hline & Estonia & Estcoin, a government backed cryptocurrency, announced in August 2017. \\
\hline & France & Tested blockchain technology in October 2016. \\
\hline & Germany & $\begin{array}{l}\text { Tested blockchain technology in December } 2016 \text { with Hyperledger blockchain } \\
\text { technology. }\end{array}$ \\
\hline & India & $\begin{array}{l}\text { Finished testing blockchain solutions for core banking processes in the country } \\
\text { in May } 2017 .\end{array}$ \\
\hline & Japan & $\begin{array}{l}\text { Japanese banks are planning to introduce a digital currency for the } 2020 \\
\text { Tokyo Olympics. }\end{array}$ \\
\hline & Netherland & $\begin{array}{l}\text { Preparing an ambitious experiment aimed at discerning if an entire financial } \\
\text { market can be built on a blockchain and testing a prototype "DNBcoin." }\end{array}$ \\
\hline & Russia & Developing a national digital currency based on Ethereum in June 2017. \\
\hline & Singapore & $\begin{array}{l}\text { Completed the first phase of that pilot in March } 2017 \text { with the Private } \\
\text { Ethereum Blockchain. }\end{array}$ \\
\hline & South Africa & $\begin{array}{l}\text { Planning to Introduce national digital currency based on blockchain in } \\
\text { February } 2017 .\end{array}$ \\
\hline & Sweden & $\begin{array}{l}\text { Considering the possibility of issuing blockchain based digital currency in } \\
\text { November 2016(no update as of December, 2017). }\end{array}$ \\
\hline & Ukraine & $\begin{array}{l}\text { The central bank began working on a blockchain-based system in November } \\
2016 \text { to develop a "cashless economy" and expanded and reinforced the team } \\
\text { in December, } 2017\end{array}$ \\
\hline
\end{tabular}

software code is a strong coercion because the law implemented in the software is difficult to violate. For example, in 2007, when the presidential election was held, Korea's No. 1 internet portal Naver, who was afraid of the conservative party, blocked the comment field of political news articles. Therefore, netizens in Korea were unable to comment at all on political news. They abruptly lost the space where they had expressed their political views or opinions so far. (I think everyone may have experienced similar situations where they could do or could not do something depending on the functions implemented in Internet services.)

Thus, individuals can only engage in activities that are allowed by the Internet services. Internet services are built by software, so we can say that software exerts "a strong coercive force" on individuals' activities. The law implemented on software is significantly stronger than the law written on paper.

The blockchain goes one step further and is an example of "absolute coercion." A blockchain cannot be tempered or forged, and therefore, the rules implemented on a blockchain cannot be changed. If we consider the code to be law, the blockchain allows the implementation of "absolute laws" that no one can violate. Blockchain can be the beginning of an entirely different phase in the history of laws. Furthermore, with this 
feature, the blockchain makes it possible to ensure "absolute trust" in society. We should note that trust has never been guaranteed absolutely before blockchain technology emerged throughout human history.

In terms of social devices that ensure trust in society, we find three kinds of trust machines in history: the reputation system, the state including government and bureaucracy, and the blockchain technology.

\section{Three types of trust machines in human history}

I distinguish here the three trust machines, or social devices, of human history that allow people to believe in and act with each other.

The first trust machine is the reputation system. This system is invisible, but regardless is functional in our daily lives. Particularly in primitive tribal communities with a small population of a hundred or so, the role of the reputation system was significantly more important than anything else. We can say that the primitive tribal communities are the pure peer-to-peer societies where everyone can interact with face-to-face communication. Through anthropology and brain science research, Robin Dunbar presented the famous Dunbar's number, $150,{ }^{13}$ indicating the number of people who can know each other well and live together with close intimacy. This scale indicates the number on which a reputation system can effectively operate. The reputation system is now a part of our daily lives, particularly in our social network.

However, beyond this number, the reputation system does not work in ordinary lives, because there is no reputational information about others. Therefore, when the number of community members exceeds the Dunbar's number, 150, society needs another trust machine to ensure the trust of the extended community. This second machine in human history is the state composed of the government and the bureaucracy that has been introduced for this purpose. There are many arguments about the origin and role of the state and government, but I think that their ultimate role is to guarantee trust in our society. In fact, the state guarantees trust in society by taking complete responsibility for jurisdiction, security, diplomacy, and national defense. Historically, if the trust in society collapses, the dynasties or political powers that have operated or dominated the state or nation also collapse and become replaced with others. Therefore, the most fundamental role of the state and government is to ensure the trust of a large community that cannot be maintained by a reputation system alone. The bureaucracy can be said to be the execution tool of the state and government to ensure trust in society.

The third trust machine, blockchain technology is emerging now. ${ }^{14}$ Blockchain technology ensures trust among anonymous individuals. Someone said that blockchain is the technology that creates the real peer-to-peer society. Interactions among people in the twenty-first century are more likely to be mediated by technology than face-toface communication. So, peer-to-peer in twenty-first century means that the interactions of individuals are mediated not by other people, other companies, or other organizations but by technologies. Therefore, it is easy to understand if we translate the word "to" in "peer-to-peer" as "technology." In other words, it would be correct to interpret peer-to-peer as "person-technology-person," or as "technology-mediated human interaction." In the era of blockchain, we must reinterpret the meaning of "to" in "Peer to Peer" as "Trust technology." We can say that the era of blockchain is one where people (peer) connect and interact with each other using trust technology. 
With the emergence of blockchain technology, the role of the state and the government that has functioned as a trust machine until now are bound to change and the mode of operation of bureaucracy will consequently change as well.

\section{The nature of bureaucracy}

The analyses of bureaucracy, so far, have focused on its moral and emotional aspects such as its inhuman characteristics or inefficiency. If you study bureaucracy only as an inhuman tool or in terms of efficiency, you will not be able to grasp why bureaucracy emerged in society. Additionally, you will also be unable to grasp how bureaucracy survived in human society for thousands of years despite the heavy and severe criticism it received. In addition, this view makes it impossible to see the essential role that bureaucracy plays in society, which also makes it impossible to see how its role will change in the future, especially in the era of blockchain.

I define the nature of bureaucracy as a social technology that works as an "information processing machine" for the community to which it belongs. In other words, bureaucracy is a social technology dedicated to the distribution and processing of information that is needed in a specific community. This is illustrated by the fact that the first bureaucrats recorded in history in the world were "scribes" in Sumer; scribes were people who recorded and managed various kinds of information on tablets. They made a lot of tablets with their early letters, which provide information of lending, debt, interest, and so on. ${ }^{15}$ Why did they have to write down the lending, debt, interest? It was an effort to maintain the trust of society in the extended community. In a large community where a reputation system does not works as a trust machine, the society can not maintain trust unless someone is managing these information. Therefore, bureaucracy is not an organization for charity, cooperation, or innovation, but an "information processing machine" that processes all kinds of information according to predefined laws. The primary role of bureaucracy is to produce and circulate information forcibly within a large community.

There are close similarities between the blockchain and bureaucracy. Bureaucracy is very similar to the tasks performed by computer systems. First, both of them are defined by the rules and execute predetermined rules. The blockchain technology is, of course, a kind of computer system and works according to the predetermined rules. Therefore, it is theoretically not problematic to claim that the blockchain technology would replace the role of bureaucracy. Second, both of them work as society's information processing machines. Third, both of them work as trust machines. Therefore, I think that not only is it possible to replace bureaucracy with the blockchain system, but that it is unavoidable.

In addition, the blockchain technology make it possible to implements the "absolute law," so it can process information more efficiently and accurately than does the bureaucracy. In addition, Smart Contracts can automate the administrative process. New bureaucratic systems based on blockchain technology would be faster, more secure, more accurate, and more efficient than traditional bureaucracies. This is why it is inevitable that the current bureaucratic system based on human activities will be replaced by a new system based on blockchain. This is why so many projects are being driven by the governments of over 40 countries within a span of 2 years.

Blockchain technology can act as a precise technology that can replace the bureaucracy, because it can create, store, and process information with safety and non-falsification. 
Furthermore, blockchain technology can handle existing governments' tasks significantly more faster and efficiently. I will call a government that uses blockchain technology as a key instrument in its work a "Blockchain Government." If this concept of a blockchain government is realized, our society will undergo revolutionary changes. Blockchain technology is a really innovative technology that can transform the very basis of our society.

\section{Blockchain government}

I suggest the principles for implementing a blockchain-based government system.

The first principle is the "Blockchain Statute law." Blockchain technology ensures "absolute coercion," thus enabling the creation of a law that cannot be violated. We can put this law on the blockchain and allow it to run automatically with Smart Contracts. We have already discussed how the code is law. It means that we should treat the rules written on the software as a level of law. The concept of Blockchain Statute law should now be introduced, since blockchain enables "absolute law" that cannot be tampered or violated. In addition, this is the only way to prevent society from falling into a catastrophe with unintended mistakes or bad intentions, particularly in the era of the Fourth Industrial Revolution ${ }^{16}$ wherein we cohabit with living things everywhere.

The second principle is "transparent disclosure," or open source strategy. The scope of the disclosure here contains from the blockchain software code itself that constitutes the public infrastructure to the data contained in it. They must be disclosed to the maximum extent possible. The Government 2.0 guide, formulated by the Australian government, ${ }^{17}$ already claims that all data, excluding the data having clear reasons for non-disclosure, should be disclosed. In addition, since the blockchain technology is a distributed ledger, it is suitable for disclosing and sharing information. There are two other reasons for claiming "Transparent disclosure." One reason why blockchain software should be disclosed is that it is necessary for everyone to be able to verify the laws embedded in the code. The other reason is that open source strategy is the best way to make software more secure and to encourage the development of an ecosystem.

The third principle is the implementation of "An automated process." This would allow us to build a significantly faster and more efficient government system. The automation of government administrative systems using Smart Contracts is already being conducted in several places. We do not need to be afraid of the automation of government administrative systems because it is possible to manage the laws implemented in the blockchain with the consent of all the community members. This leads to the following fourth principle.

The fourth principle is to build "A direct democratic governance system." Many projects have already been implemented to rebuild existing voting systems using blockchain technology worldwide, but we can think beyond the voting system we have known so far. The laws that are implemented in the blockchain can be determined and revised through a consensus process involving all community members. In other words, we can build a mechanism that allows to modify "the law" stored in the blockchain automatically through democratic voting and consent of all community members. Several blockchain projects that aim to overcome the shortcomings of Bitcoin or Ethereum blockchains are attempting to implement automated revision with the consensus of the participants of the blockchain network. ${ }^{18}$ Although it is not easy to apply this 
feature to the current administration system, we can apply this feature to the Blockchain government in the near future.

The fifth principle is building a Distributed Autonomous Government (DAG). If all of us, the entire community, participates and provides consent for government laws through a consensus process, and make it run on a blockchain automatically, we can create a government that is completely different from existing governments. It means that it is possible to construct a government system as a social operating infrastructure, as an information processing machine of the community that executes automatically and whose rules are decided with the consent of the whole community. Such a government can be termed DAG.

\section{Conclusion}

It can be said that the blockchain technology will be a great tool for social innovation not only for the enhancement of the effectiveness of government but for the innovation of society from the grassroot. But blockchain is not a fully developed technology but an emerging one. We need more time to harness the full potential of blockchain technology, and several tasks must be solved. Here, I suggest the tasks that need to be improved or supplemented in the future.

The first is to ensure the integrity of the program. We have experienced that there is a loophole in Ethereum's Smart Contracts with "The DAO" project. ${ }^{19}$ Therefore, it is necessary to find a way to supplement the shortcomings of Smart Contracts. Several projects such as BOScoin, Tezos, Qtum, EOS and Cardano are aiming to find alternative ways to build a more secure and efficient Smart Contracts platform.

The second issue is to introduce a governance feature, a consensus mechanism involving all network participants, in order to modify and revise the blockchain algorithm itself. This function is introduced now in newly designed blockchains such as Tezos, BOScoin and Cardano. I think that these new concepts of Blockchains will form the third wave of blockchain technology.

The third issue is performance. Bitcoin processes transactions approximately four times per second, and Ethereum can only process transactions nine times per second at most. It is difficult to expand the usage of the blockchain technology without increasing the processing performance. Fortunately, many different algorithms have been developed now to improve the performance of blockchains significantly. Therefore, it is a matter of time before we can solve the performance issue.

The fourth is to make it possible to accommodate the private data in public blockchains, such as personal identity (sex, age, name, address and etc.), health record, private keys, or ownership of assets. Ordinarily, the data in public blockchains is made transparent to everyone; therefore, it is almost impossible to accommodate private data in it. However, if we plan to use blockchain technology widely including for identification, secret ballots, health record management or so, we need another technology, such as Zero knowledge proof, Multi-party computation, or Homomorphic Encryption algorithm, that can handle the secret and private data in the blockchain. Several projects, such as Zcash and Zcoin are currently attempting to develop this technology.

Finally, there may be an epistemological repulsion towards the idea of an automated system based on blockchains replacing our familiar public domains, such as bureaucracy. It is necessary for society to admit that these kinds of transformation are inevitable and to 
conduct open discussions to reduce the fear and side effects of introducing new and revolutionary technologies.

\section{Endnotes}

${ }^{1}$ Walport 2015.

${ }^{2}$ Rizzo 2016.

${ }^{3}$ Higgins 2017.

${ }^{4}$ Jun 2017.

${ }^{5}$ Swan 2015.

${ }^{6}$ Nelson and Nelson 2002.

${ }^{7}$ Dougherty 2017.

${ }^{8}$ Nakamoto 2008.

${ }^{9}$ Kang 2014.

${ }^{10}$ Lessig 2000.

${ }^{11}$ Buterin 2014.

${ }^{12}$ Tapscott and Tapscott 2016.

${ }^{13}$ Dunbar 1993.

${ }^{14}$ Berkeley 2015.

${ }^{15}$ Robson 2000.

${ }^{16}$ To understand the features of Fourth Industrial Revolution, see Hang Sik Park (2017).

${ }^{17}$ Australian Government 2009.

${ }^{18}$ Bitcoin has not been able to improve performance for many years because the miners could not reach consensus on how to improve the algorithm. Ethereum also experienced same problem when The DAO accident happened. This resulted in the separation of Ethereum and Ethereum Classic. This allowed for two consensus blockchain algorithms: one for the data, and the other for the rules implemented in the blockchain. This mechanism is already being implemented in new blockchains like Tezos, BOScoin, Dfinity, Cardano, etc. See MyungSan Jun (2017).

${ }^{19}$ Siegel 2016.

Acknowledgements

Not applicable.

Funding

Not applicable.

Availability of data and materials

Not applicable.

Author's contributions

Not applicable.

\section{Author's information}

MyungSan Jun graduated with a bachelor's degree from the Division of Sociology, Seoul National University in Korea In 1995 He has worked in the IT industry for 20 years including Cyworld, the world's first successful social network service (SNS). He published a book, From the State to the Village in 2012, which analyzed the communication structure of twenty-first century. This book was selected as an "Excellent literary book" in 2012 by the Ministry of Culture and Tourism, Korea. He also writes IT columns for various journals in Korea. In 2017, he published his second book, Blockchain Government, in Korea in which he investigates the relationship between the government and blockchain. He now works for BlockchainOS Inc., a blockchain tech company. 


\section{Publisher's Note}

Springer Nature remains neutral with regard to jurisdictional claims in published maps and institutional affiliations.

Received: 12 October 2017 Accepted: 23 January 2018

Published online: 13 February 2018

\section{References}

Australian Government (2009) Report of the Government 2.0 Taskforce, "Engage: Getting on with Government 2.0".

Berkeley, J. (2015) "The Trust machine - The technology behind bitcoin could transform how the economy works," The Economist.

Buterin, V. (2014) "A Next-Generation Smart Contract and Decentralized Application Platform". https://github.com/ ethereum/wiki/wiki/White-Paper.

Dougherty, D. (2017) 'Taking advantage of emergence for complex innovation eco-systems', "Journal of Open Innovation: Technology, Market, and Complexity", Keynote paper for SOltmC \& Riga Technical University 2017 Conference. https://doi.org/10.1186/s40852-017-0067-y.

Dunbar, R. I. M. (1993). Coevolution of neocortical size, group size and language in humans. Behavioral and Brain Sciences, 16(4), 681-735

Higgins, S. (2017) "IBM: Nine in 10 Government Execs Plan to Invest in Blockchain By 2018," Coindesk.

Jun, M.S. (2017a) "How to Solve Consensus Conflicts in Blockchain," Medium. https://medium.com/boscoin/how-tosolve-consensus-conflicts-in-blockchain-661982f466c3\#.nk16p2d0r.

Jun, M.S. (2017b) 'Blockchain Government', Alma: (published in Korea).

Kang, J. (2014) "Algorithm Society 1: Algorithm, change the order of labor and society," Slow News. http://slownews.kr/ 19042

Lessig, L. (2000) "Code: And Other Laws of Cyberspace", Basic Books.

Nakamoto, S. (2008) "Bitcoin: A Peer-to-Peer Electronic Cash System", https://bitcoin.org/bitcoin.pdf

Nelson, R.R. \& Nelson, K. (2002) "Technology, institutions, and innovation systems", Research Policy.

Park, H.S. (2017) Technology convergence, open innovation, and dynamic economy', "Journal of Open Innovation: Technology, Market, and Complexity". https://doi.org/10.1186/s40852-017-0074-z.

Rizzo, P. (2016) "Blockchain to Drive Wanxiang's \$30 Billion Smart Cities Initiative," Coindesk

Robson, E. (2000) 'The uses of mathematics in ancient Iraq, 6000-600 BC', "MATHEMATICS ACROSS CULTURES: THE HISTORY OF NON-WESTERN MATHEMATICS" edited by Helaine Selin, Kluwer Academic Publishers.

Siegel, D. (2016) "Understanding The DAO Attack," Coindesk.

Swan, M. (2015) "Blockchain: Blueprint for a New Economy", O'Reilly Media.

Tapscott, D.; Tapscott, A. (2016) "Blockchain Revolution", Penguin Random House UK.

Walfort, M. (2015) "Distributed Ledger Technology: Beyond block chain", A report by the UK Government Chief Scientific Adviser.

\section{Submit your manuscript to a SpringerOpen ${ }^{\circ}$} journal and benefit from:

- Convenient online submission

- Rigorous peer review

- Open access: articles freely available online

- High visibility within the field

- Retaining the copyright to your article 